\title{
Determination of toxicity of various preparative forms of pesticidal fungicides for nodule bacteria inoculants
}

\author{
$Y V$ Laktionov $^{1, *}, Y V$ Kosulnikov $^{1}, V V$ Yachno $^{1}$, and $A P$ Kozhemyakov $^{1}$ \\ ${ }^{1}$ All-Russia Research Institute for Agricultural Microbiology, Podbelsky Chaussee, 3, 196608, \\ Pushkin, St. Petersburg, Russia
}

\begin{abstract}
The aim of our study was to determine the effect of fungicide formulation, brand of fungicide, its concentration in the solution, holding time and temperature regime of the solution on the number of survivors of nodule bacteria of soybean, lupine, peas and lentils in a solution. Bacterial suspensions of soybean nodule bacteria (Bradyrhizobium japonicum 634b), lupine (Bradyrhizobium lupini 367a), pea (Rhizobium leguminosarum 261b), and lentils (Rhizobium leguminosarum 712) were studied. Wetting powders Benomil (active substance benomil $500 \mathrm{~g} / \mathrm{kg}$, LLC "Soyuzagrohim", Russia), Benorad (active substance benomil $500 \mathrm{~g} / \mathrm{kg}$, JSC "August", Russia) and Fundazol (active substance benomil 500 g/l, LLC "Agro-Kemi", Russia) and concentrates of suspension Maxim KS (active substance fludioxonil, $25 \mathrm{~g} / \mathrm{l}$; "Syngenta International AG", Switzerland), Protect KS (active substance fludioxonil, 25 g/l; LLC "Agro Expert Group", Russia), Protect Forte VSK (active substance fludioxonil, 40 g/1 + flutriafol, 30 g/l; LLC “Agro Expert Group”, Russia) were studied as fungicidal disinfectants. Compatibility was determined after the preparation of tank solutions of biological products and fungicides, followed by an assessment of the percentage of surviving rhizobia depending on the brand of fungicide, its concentration (10 and 20\%), the holding time of the solution $(2,4,8 \mathrm{~h})$ and the temperature regime of the solution $\left(2-5,16-18,27^{\circ} \mathrm{C}\right)$.
\end{abstract}

\section{Introduction}

Legumes are the main source of plant protein [1]. The average yield of legumes in Russia is much lower than in Europe and the United States [2-3]. This phenomenon is caused, among other things, by the lack of justified regulations for the effective use of microbiological preparations in combination with chemical plant protection products [4-8].

Unfortunately, the study of the compatibility of biological products and fungicides clearly lags behind the emergence of inoculants based on new strains [9-10] and changes in the technology of production of fungicides under the same brand [11-12]. Fungicides (herbicides, fungicides, insecticides, etc.) have long been shown to be effective, their

\footnotetext{
* Corresponding author: Laktionov@list.ru
} 
application methods have been developed [13-14] and are fixed in domestic agricultural practice. Therefore, if there are doubts about the effectiveness of the combined use of biological and chemical preparations, agricultural producers give preference to the latter [15-16]. In other words, the lack of scientific works on assessing the compatibility of microbiological and chemical methods of processing leguminous seeds [17-18] may cause rejection of biological products, despite their environmental friendliness [19-20], costeffectiveness [21] and efficiency [22-23].

Analysis of domestic and foreign literature on the toxicity factors of fungicides for bacteria has shown that the active substances of most fungicides are defined by researchers as more or less toxic to rhizosphere microorganisms [26-27], including nodule bacteria [2829]. There is evidence [30] that the contact of soybean rhizobia on inoculated seeds with such common fungicides as captan and tiram (contact fungicides), as well as benomil, carbendazim, diphenoconazole and tebuconazole (systemic fungicides) causes a significant reduction in the number of viable bacteria. According to work [32], fludioxonyl has a significant toxic effect on soy rhizobia. The authors of the study claim that the contact of soy rhizobia with fludioxonyl on inoculated seeds significantly reduces the number of surviving bacteria compared to the control 24 and 48 hours after inoculation. At the same time, not all active substances of fungicides are unambiguously toxic to all brands and strains of rhizobia - in work [31], the researcher identified pea rhizobia as resistant to benzimidazoles.

There are reports that different brands of fungicides [35] and different temperature regimes during storage of tank solutions have a noticeable effect on the survival rate of bacteria in such solutions. A number of studies have shown the ability of rhizobia to decompose pesticides [36], which, however, is a fairly common ability among rhizosphere microorganisms [37]. According to a number of data [38, 39], slow-growing soybean rhizobia Bradyrhizobium japonicum and fast-growing soybean rhizobia Sinorhizobium fredii are able to grow on a mineral-vegetable agar medium with the addition of a production concentration of the fungicide Maxim. The growth rate is either not inferior to the growth of bacteria in the control [38], or slightly reduced [39].

It is worth noting that the absence of an obvious toxic effect of the fungicide on rhizobia in a joint tank solution does not guarantee the absence of negative consequences for nodule formation in the field [40-42]. For example, a number of studies have described the inhibitory effect of the fungicide Maxim on the intensity of nodule formation in inoculated soybean plants [24], despite the fact that seed treatment and inoculation were separated in time. On the other hand, some authors indicate [39] that the treatment of soybean seeds with the Maxim fungicide with their simultaneous inoculation provides a more intensive nodule formation, an increase in aboveground mass, and a significant increase in yield compared to the variant where the seed treatment was carried out with a solution of only one inoculant.

This study is the first to present data confirming that the compatibility of inoculants and fungicides based on the same active substance is significantly affected by the method of production of the fungicide, i.e. the qualitative and quantitative composition of additional components, which, from the point of view of the manufacturer, increases the manufacturability of the drug itself - the so-called "formulation" of the fungicide (filmforming polymers, adjuvants, surfactants, etc.). Also in this study, the influence of the temperature regime of the tank solution on the survival of rhizobia inoculants was determined and the dynamics of bacterial death on seeds inoculated simultaneously with their treatment was determined. These data supplement the limited information that concerns the compatibility of preparations of nodule bacteria and chemical means of protecting legumes. 


\section{Materials and methods}

Our aim was to determine the effect of formulation of the fungicide, brand of fungicide, its concentration in solution, the holding time of the solution and temperature regime on the dynamics of the death of nodule bacteria of soybean, lupine, peas and lentils in both the tank solution with pesticides, and treated by them seeds.

Strains of soybean nodule bacteria (Bradyrhizobium japonicum 634b), lupine (Bradyrhizobium lupini 367a), pea (Rhizobium leguminosarum 261b) and lentils (Rhizobium leguminosarum 712) were obtained from the departmental collection of useful agricultural microorganisms of the All-Russian Research Institute of Agricultural Microbiology (ARRIAM, Saint Petersburg). The choice of microorganism strains was determined by the greatest practical significance of crops (soy, lupine, pea, lentils) in modern Russia and the CIS countries. In Russia on the basis of these strains produce biological products for legumes under the commercial name Risotorphine ${ }^{\circledR}$ (manufacturer is ARRIAM). Bacterial cultures were prepared on a semi-synthetic medium $(0.5 \mathrm{~g} / \mathrm{l}$ K2HPO4, $0.2 \mathrm{~g} / 1 \mathrm{MgSO} 4\lfloor 7 \mathrm{H} 2 \mathrm{O}, 0.1 \mathrm{~g} / 1 \mathrm{NaCl}, 1.0 \mathrm{~g} / 1$ yeast extract, $10.0 \mathrm{~g} / 1$ mannitol), followed by cultivation on a BioSan ES-20/60 shaker incubator, $170 \mathrm{rpm}$, Latvia. As a seed material for processing with varieties used soybean seeds of the Belgorodskaya 7 variety.

For the preparation of tank solutions with inoculants, the following chemical fungicides were used: wetting powders Benomil (active substance benomil $500 \mathrm{~g} / \mathrm{kg}$, LLC "Soyuzagrohim", Russia), Benorad (active substance benomil 500 g/kg, JSC "August", Russia) and Fundazol (active substance benomil 500 g/l, LLC "Agro-Kemi”, Russia) and concentrates of suspension Maxim KS (active substance fludioxonil, $25 \mathrm{~g} / \mathrm{l}$; "Syngenta International AG", Switzerland), Protect KS (active substance fludioxonil, $25 \mathrm{~g} / \mathrm{l}$; LLC "Agro Expert Group", Russia), Protect Forte VSK (active substance fludioxonil, 40 g/l + flutriafol, $30 \mathrm{~g} / \mathrm{l}$; LLC "Agro Expert Group", Russia). The choice of pesticide brands for the study was due to their widespread use in modern Russia and the CIS countries as fungicidal seed disinfectants for legumes.

Variants of working solutions of fungicides and nodule bacteria were mixed $(20 \%$ solution of bacterial suspension with $10 \%$ and $20 \%$ solutions of the fungicide of each test brand) and kept in a refrigerator $\left(2-5{ }^{\circ} \mathrm{C}\right)$, at room temperature $\left(16-18{ }^{\circ} \mathrm{C}\right)$ and in a thermostat $\left(27.5^{\circ} \mathrm{C}\right)$. At certain time intervals $(0,1,2,4$, and 8 hours $)$, a sample of each variant was taken, a series of dilutions was prepared, and sown on Petri dishes with agar nutrient medium $\left(20 \mathrm{~g} / \mathrm{l}\right.$ agar-agar, $0.5 \mathrm{~g} / 1 \mathrm{~K}_{2} \mathrm{HPO}_{4}, 0.2 \mathrm{~g} / 1 \mathrm{MgSO}_{4} \succeq 7 \mathrm{H}_{2} \mathrm{O}, 0.1 \mathrm{~g} / 1 \mathrm{NaCl}, 1.0$ $\mathrm{g} / \mathrm{l}$ yeast extract, $10.0 \mathrm{~g} / \mathrm{l}$ mannitol). After 10 days of thermostating, the number of colonyforming unit (CFU) of rhizobia was calculated and, thus, the titer of bacteria in each variant of the tank solutions was determined.

Inoculation of seeds with variants of tank solutions was performed as follows:

Preparation of a sample of seeds in a Petri dish in the amount of $25 \mathrm{~g}$.

Inoculation of seeds in a Petri dish with a $20 \%$ solution of bacterial suspension in tap water (control version), or in a tank solution with a fungicide (experimental versions).

The number of viable bacteria per 1 inoculated seed was determined as follows:

Placing 8 inoculated seeds from a Petri dish in a test tube with $8 \mathrm{ml}$ of pre-sterilized water, followed by shaking it on a vortex for $1 \mathrm{~min}$.

Preparation of a series of consecutive dilutions of the received flushing from seeds with their subsequent sowing on Petri dishes with agar nutrient medium.

Calculation of the formed bacterial colonies typical for the studied bacterial culture. Using the resulting number to determine the number of bacteria per 1 inoculated seed.

Statistical data processing was performed using Microsoft Excel 10. To confirm the validity of the differences between the variants, the figures show the average values (M) 
and standard errors of the averages $( \pm \mathrm{SEM})$. Differences were evaluated by the Student's ttest and considered statistically significant at $\mathrm{p}<0.05$. The experience is repeated 3 times.

\section{Results}

It was determined that several brands of benomil - based wetting powders widely used in conjunction with inoculants were significantly toxic to soy rhizobia (fig. 1).

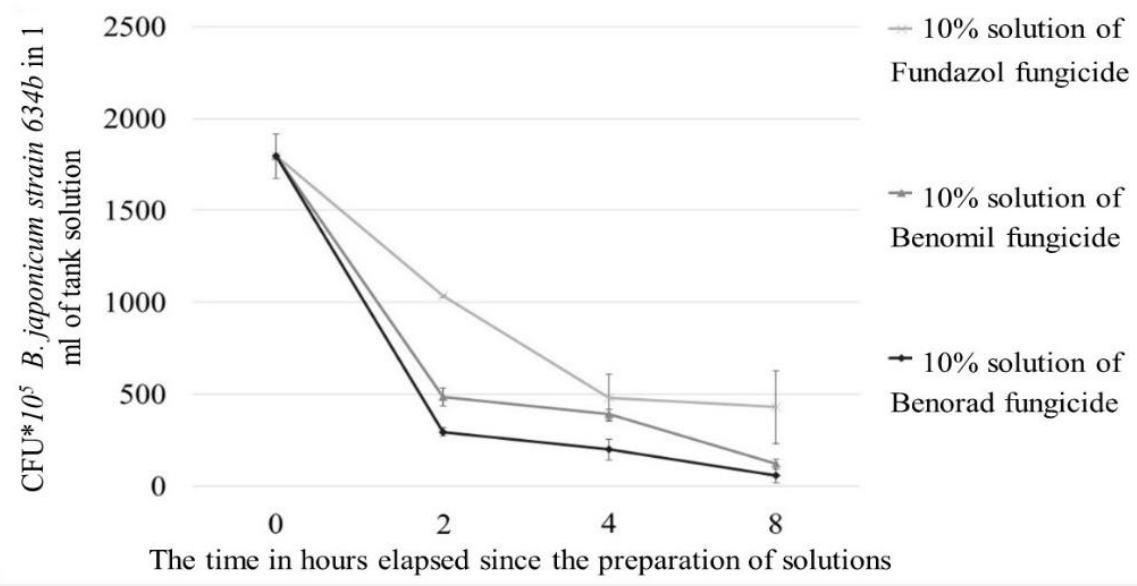

Fig. 1. Effect of $10 \%$ solutions of Fundazol, Benomil and Benorad fungicides on the survival of soybean rhizobia B. japonicum strain $634 b$ in tank solution.

The graphs show that all 3 fungicides differ significantly in their toxicity to soy rhizobia. So, if $10 \%$ Fundazol 8 hours after the preparation of the tank solution reduces the number of bacteria by 3-3.5 times, then 10\% Benomil and Benorad for 8 hours of contact with rhizobia reduce the number of the latter by almost an order of magnitude. In other words, all 3 wetting powders, despite the same active substance and its concentration in the fungicide, it was possible to build up a fairly definite series to increase toxicity for soy rhizobia: Fundazol, Benomil, Benorad.

Repeating a similar experiment with rhizobia lentils R. Leguminosarum strain 2720 , revealed a greater sensitivity of this type of bacteria to the studied fungicides. Of all the variants of the experiment, the colony bacteria for counting were obtained only in the variants with the Fundazol fungicide and only for 4 hours of holding tank samples (fig. 2). 


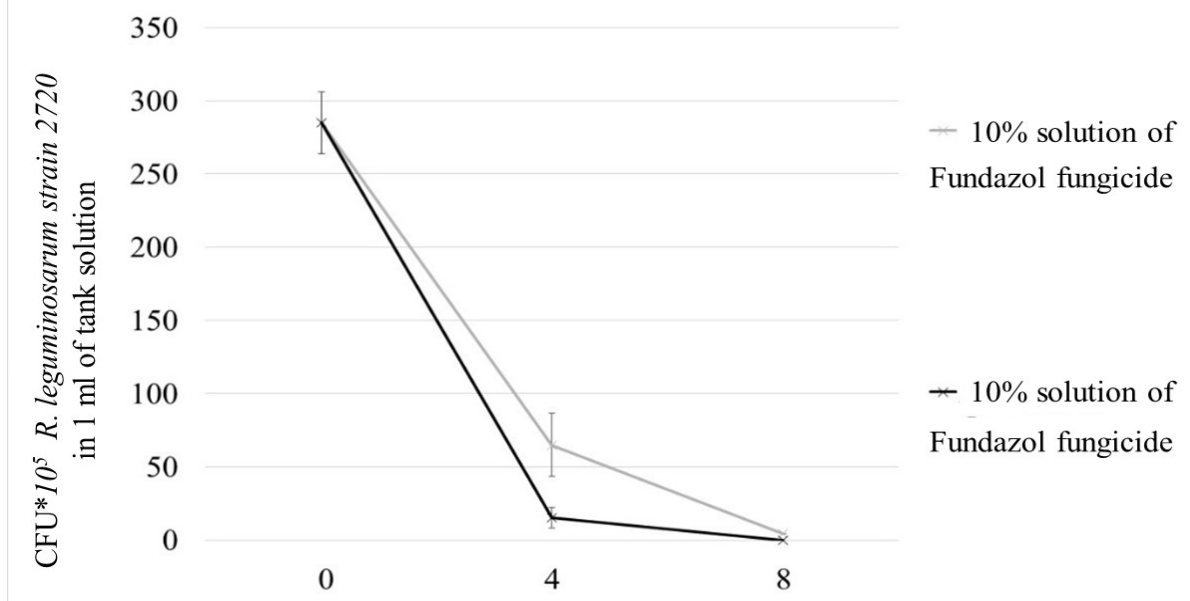

The time in hours elapsed since the preparation of solutions

Fig. 2. Effect of $10 \%$ and $20 \%$ solutions of Fundazol fungicide on the survival of lentils rhizobia R. leguminosarum strain $634 \mathrm{~b}$ in tank solution.

This provision confirms, firstly, the comparative low toxicity of the Fundazol fungicide for rhizobia (in comparison with other benomil - based fungicides), and secondly, the different resistance of different types of rhizobia to the same fungicides. For benomil based powdered fungicides, soy rhizobia can be called resistant, and lentils rhizobia can be called sensitive.

Mixing of fungicidal concentrates of suspensions with rhizobia preparations also negatively affected the survival of the latter. The resistance of nodule bacteria of different legumes to this pesticide formulation was different and decreased in sequence: soybean rhizobia, lupine rhizobia, pea rhizobia, lentils rhizobia. The toxicity of pesticides increased in this order: Maxim, Protect, Protect Forte (fig. 3).

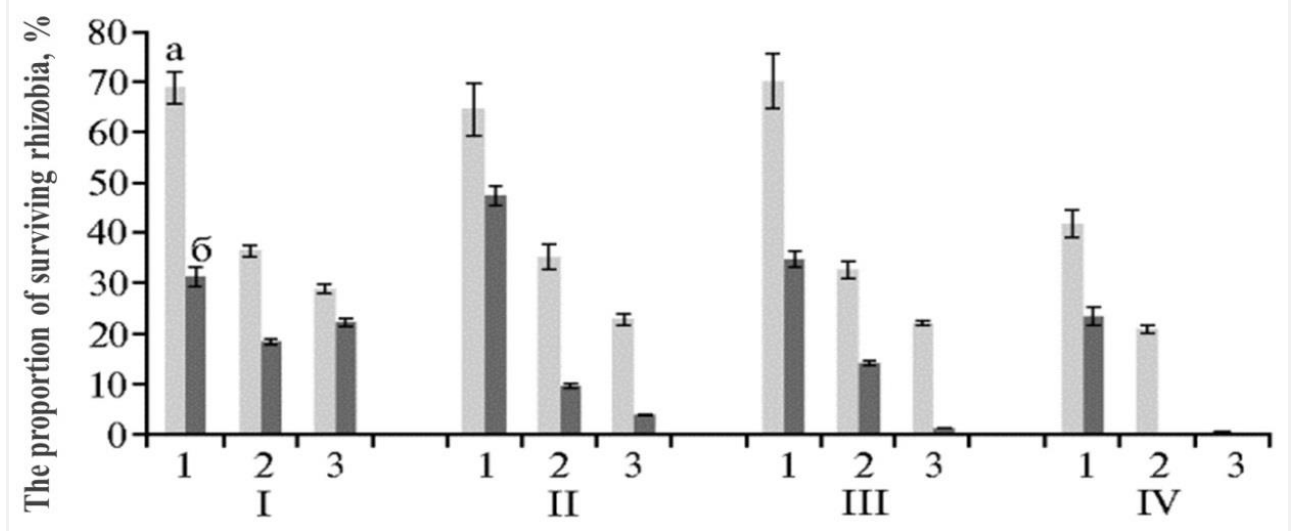

Fig. 3. The proportion of surviving rhizobia B. japonicum $634 \mathrm{~b}$ (I), B. lupini $367 \mathrm{a}$ (II), $R$. leguminosarum 260b (III) and R. leguminosarum 712 (IV) in a mixture with $10 \%$ (a) and $20 \%$ (b) solutions of fungicides Maxim (1), Protect (2) and Protect Forte (3) (a mixture of cultures and fungicides was kept for 8 hours at $16-18^{\circ} \mathrm{C}$ ).

The results of the above graph show that the nature and concentration of the active substance of fungicide do not clearly determine the dynamics of reducing the number of 
rhizobia. For example, the Maxim fungicide, which is the least toxic for all the studied rhizobia species, contains the same active substance in the same concentration as the much more toxic Protect fungicide. The toxicity of the Protect fungicide for soybean and lupine rhizobia was comparable to that of Protect Forte (see table 1), despite the fact that the latter concentration of fludioxonyl is almost 2 times higher, and there is also a second active substance - flutriaphol.

Table 1. The proportion of surviving rhizobia in a mixture with 10 and $20 \%$ solutions of fungicides $\left(16-18{ }^{\circ} \mathrm{C}\right)$ depending on the time since mixing $(M \pm \mathrm{SEM})$.

\begin{tabular}{|c|c|c|c|c|c|c|c|c|}
\hline \multirow{4}{*}{$\begin{array}{c}\text { Time, } \\
\mathrm{h}\end{array}$} & \multicolumn{8}{|c|}{ Rhizobia and concentration of fungicide } \\
\hline & \multicolumn{4}{|c|}{ Bradyrhizobium } & \multicolumn{4}{|c|}{ Rhizobium } \\
\hline & \multicolumn{2}{|c|}{ japonicum 634} & \multicolumn{2}{|c|}{ lupini $367 \mathrm{a}$} & \multicolumn{2}{|c|}{ leguminosarum $261 \mathrm{~b}$} & \multicolumn{2}{|c|}{ leguminosarum 712} \\
\hline & $10 \%$ & $20 \%$ & $10 \%$ & $20 \%$ & $10 \%$ & $20 \%$ & $10 \%$ & $20 \%$ \\
\hline \multicolumn{9}{|c|}{ Maxim, KS } \\
\hline 2 & $79.02 \pm 4.95$ & $67.31 \pm 3.56$ & $82.56 \pm 5.64$ & $73.76 \pm 4.26$ & $83.43 \pm 5.23$ & $81.6 \pm 5.26$ & $81.67 \pm 5.27$ & $63.33 \pm 3.21$ \\
\hline 4 & $75.52 \pm 4.20$ & $65.91 \pm 3.24$ & $75.36 \pm 4.58$ & $69.92 \pm 3.98$ & $74.11 \pm 4.13$ & $67.2 \pm 3.89$ & $71.67 \pm 7.13$ & $60.00 \pm 3.14$ \\
\hline 8 & $68.88 \pm 3.98$ & $31.12 \pm 1.72$ & $64.48 \pm 3.67$ & $47.36 \pm 2.58$ & $70.19 \pm 3.98$ & $34.7 \pm 1.94$ & $41.67 \pm 2.10$ & $23.33 \pm 0.79$ \\
\hline \multicolumn{9}{|c|}{ Protect, KS } \\
\hline 2 & $75.20 \pm 4.45$ & $50.30 \pm 3.12$ & $60.69 \pm 3.33$ & $33.49 \pm 1.49$ & $62.58 \pm 3.09$ & $31.11 \pm 1.21$ & $81.67 \pm 5.28$ & $13.41 \pm 0.26$ \\
\hline 4 & $58.57 \pm 2.89$ & $32.47 \pm 1.32$ & $48.43 \pm 2.98$ & $25.63 \pm 0.71$ & $52.02 \pm 2.27$ & $22.14 \pm 0.76$ & $71.67 \pm 7.16$ & $3.66 \pm 0.19$ \\
\hline 8 & $36.25 \pm 1.97$ & $18.23 \pm 0.45$ & $35.06 \pm 1.73$ & $9.43 \pm 0.14$ & $32.52 \pm 1.67$ & $13.98 \pm 1.05$ & $41.67 \pm 2.13$ & 0.00 \\
\hline \multicolumn{9}{|c|}{ Protect Forte, VSK } \\
\hline 2 & $69.73 \pm 3.64$ & $52.93 \pm 3.16$ & $55.03 \pm 3.57$ & $38.76 \pm 2.03$ & $39.00 \pm 1.99$ & $17.00 \pm 0.54$ & $2.62 \pm 0.16$ & 0.00 \\
\hline 4 & $46.12 \pm 2.31$ & $27.73 \pm 0.86$ & $46.64 \pm 2.75$ & $18.12 \pm 0.41$ & $36.00 \pm 1.75$ & $14.00 \pm 0.34$ & $1.07 \pm 0.12$ & 0.00 \\
\hline 8 & $28.68 \pm 0.95$ & $22.03 \pm 0.69$ & $22.65 \pm 0.74$ & $3.69 \pm 0.10$ & $22.00 \pm 0.68$ & $1.00 \pm 0.12$ & $0.12 \pm 0.10$ & 0.00 \\
\hline
\end{tabular}

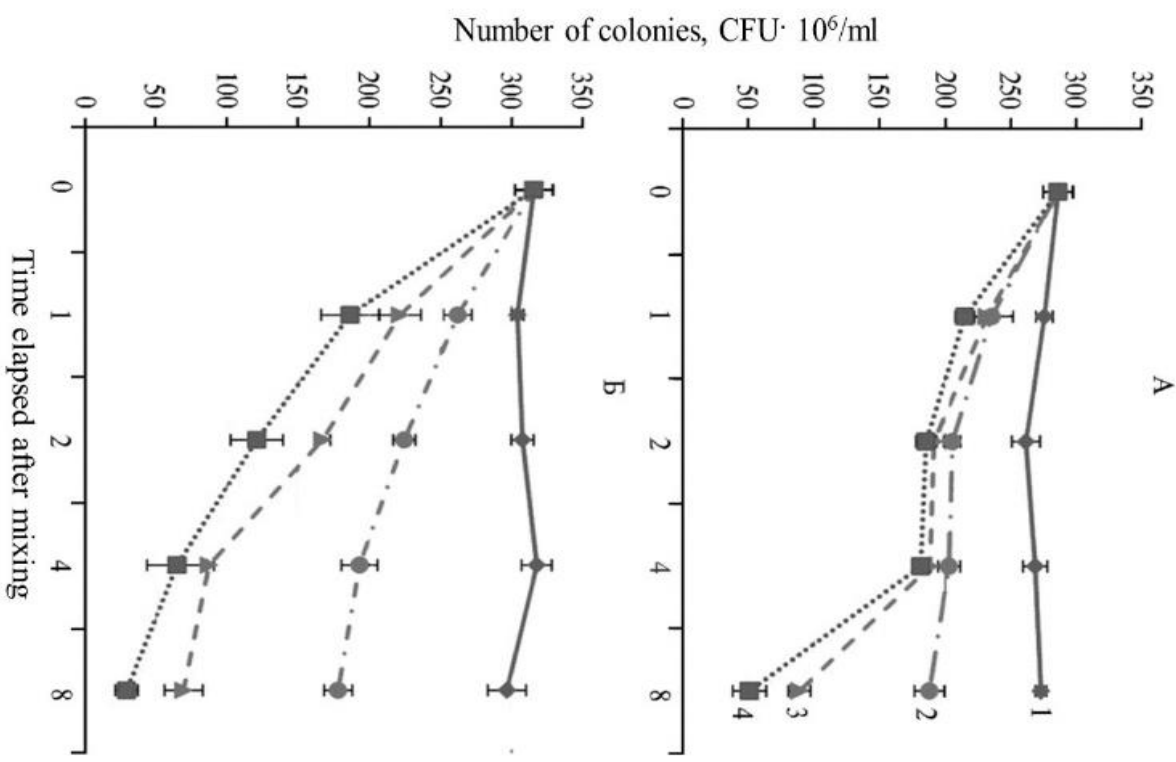

Fig. 4. Number of colonies of Bradyrhizobium japonicum $634 \mathrm{~b}$ in solution with $20 \%$ fungicides Maxim (A) and Protect Forte (B) depending on the temperature regime of the mixture: 1 - room temperature, $2-2-5^{\circ} \mathrm{C}, 3-16-18^{\circ} \mathrm{C}, 4-27.5^{\circ} \mathrm{C}$.

The more toxic the fungicide was for rhizobia, the more clearly the positive effect of low temperatures on the survival of nodule bacteria was manifested. The role of the 
temperature factor increased with increasing concentration of the fungicide. Thus, the proportion of surviving soybean nodule bacteria in a mixture with $10 \%$ Maxim fungicide solution 8 hours after mixing at $2-5{ }^{\circ} \mathrm{C}$ and $16-18{ }^{\circ} \mathrm{C}$ was 72.02 and $68.88 \%$, respectively. At the same time, values of 65.73 and $31.12 \%$ were obtained for $20 \%$ solution of fungicide. The revealed regularity was valid for each studied pair of biological product - fungicide.

The question of how the dynamics of rhizobia death changes in a mixture with a fungicide on treated seeds was studied by treating soybean seeds of the Belgorodskaya variety with joint tank solutions of inoculant $B$. japonicum strain $634 \mathrm{~b}$ and fungicides Maxim and the Protect with subsequent preparation of flushes from seeds and their sowing on Petri dishes (fig. 5,6).

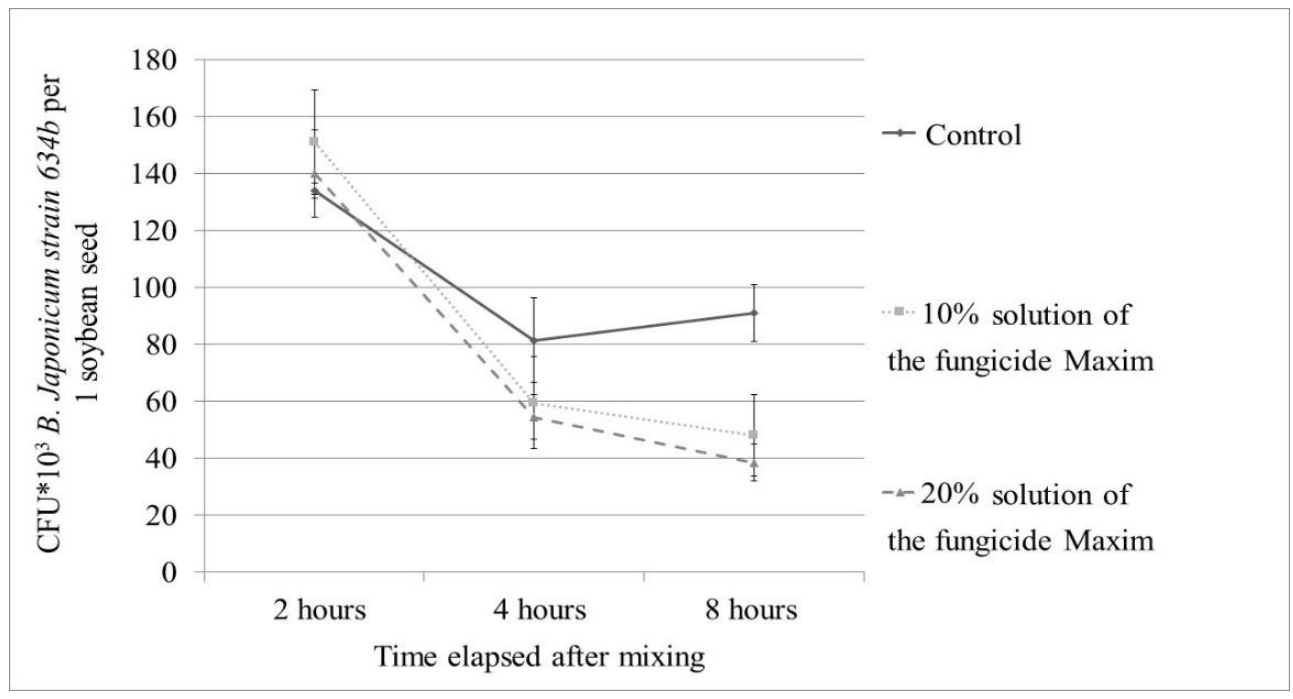

Fig. 5. Dynamics of reduction in the number of CFU of B. Japonicum strain $634 \mathrm{~b}$ per 1 soybean seed, when inoculated together with treatment by $10 \%$ and $20 \%$ solution of the fungicide Maxim.

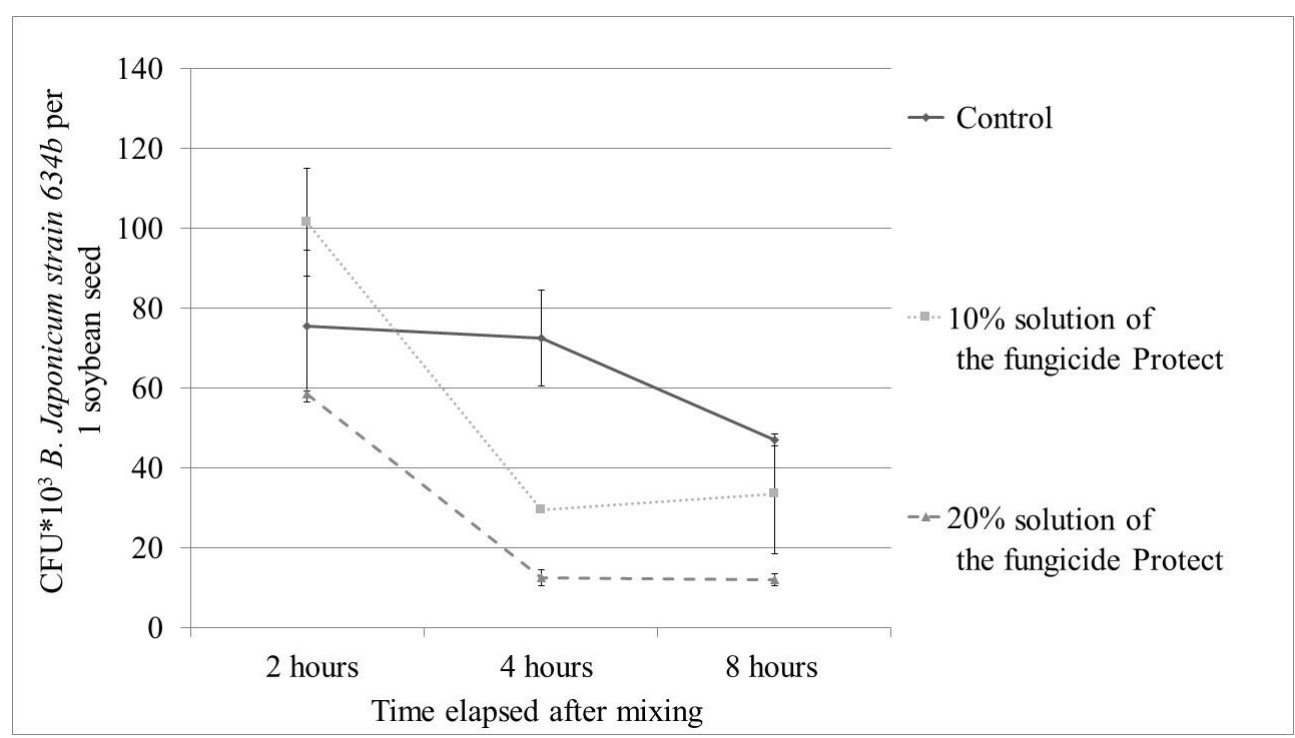

Fig. 6. Dynamics of reduction in the number of CFU of B. Japonicum strain $634 \mathrm{~b}$ per 1 soybean seed, when inoculated together with treatment by $10 \%$ and $20 \%$ solution of the fungicide Protect. 
The fungicide Protect was expected to be more toxic to rhizobia than the fungicide Maxim. Interestingly, for the fungicide Protect in $10 \%$ concentration, there is a slight excess of the number of surviving rhizobia on the treated seeds compared to the control (up to 4 hours). Probably, the formation of the fungicide to some extent contributes to a more uniform application of bacteria to the seeds, as well as their certain fixation in polymer films.

In contrast to the Maxim fungicide, the concentration of the fungicide begins to play a significant role for fungicide Protect in relation to toxicity for rhizobia. The toxicity of fungicide Protect for rhizobia increases almost linearly with an increase in its concentration from $10 \%$ to $20 \%$ in the composition of the tank solution.

\section{Conclusion}

Summing up, we can say that among the studied rhizobia, soy nodule bacteria (Bradyrhizobium japonicum 634b) were the most resistant to fungicides, and lentils nodule bacteria (Rhizobium leguminosarum 712) were the least resistant. Wetting powders based on benomil (Fundazol, Benomil, Benorad) can be defined as incompatible with inoculants. The studied fungicidal suspension concentrates (Maxim, Protect, Protect Forte) showed their relative compatibility with inoculants, since soy rhizobia in a $20 \%$ solution of the most toxic Protect Forte perished only by $80 \%$ in 8 hours of contact. It is noteworthy that the powders Fundazol, Benomil, and Benorad, as well as the fungicides Maxim and Protect, prepared on the basis of the same active substance with the same concentration, sharply differed in their toxicity for all the studied rhizobia strains.

Probably, the toxicity of these fungicides for nodule bacteria is associated not only and not so much with the active substances in their composition, but with those additional components (film-forming polymers, surfactants, emulsifiers, antiseptics, etc.) that a particular manufacturer adds to a particular brand of fungicide to improve its technological properties (formulation of the preparative form of the fungicide). It has been shown that the toxicity of pesticides for nodule bacteria increases with an increase in the concentration of fungicides and an increase in the temperature of tank solutions. Accordingly, reducing the time of contact between pesticides and inoculant bacteria and lowering the temperature of tank solutions $\left(2-5^{\circ} \mathrm{C}\right)$ significantly increases the survival rate of rhizobia. It was shown that the dynamics of death of soybean rhizobia in contact with the fungicides Maxim and Protect differs in the conditions of the tank solution and on the surface of the treated seeds. In soybean seeds inoculated together with treatment by $20 \%$ Protect Forte fungicide, the number of surviving rhizobia after 8 hours was only 2.5 times less than in the case of seeds treated with only one inoculant.

This work was performed in the framework of the state task No 0664-2019-0026.

\section{References}

1. Zotikov V I, Gryadunova N V, Naumkina T S, Sidorenko V S 2014 Leguminous crops in the Russian economy Agriculture 4 6-8

2. John R P, Tyagi R D, Brar S K, Prevost D 2010 Development of emulsion from rhizobial fermented starch industry wastewater for application as Medicago sativa seed coat Eng. Life Sci. 10(3) 248-56 doi: 10.1002/elsc.201000002

3. Suzaki T, Yoro E, Kawaguchi M 2015 Leguminous plants: inventors of root nodules to accommodate symbiotic bacteria Int. Rev. Cel. Mol. Bio. 316 111-58 doi: 10.1016/bs.ircmb.2015.01.004 
4. Nikitin S N, Zavalin A A 2017 Influence of fertilizers and biologics on the productivity of grain-fallow crop rotation, flows of nutrients and properties of leached black earth in the forest-steppe of the middle Volga region Agrochemistry 6 12-29

5. Zherukov B H 2010 Biological nitrogen in agriculture: problems, solutions and development prospects Proceedings of the Gorsky State Agrarian University 47(2) 437

6. Mirkin B M, Naumova L G 2003 Fundamentals of general ecology (Moscow)

7. Beveridge C A, Mathesius U, Rose R J, Gresshoff P 2007 Common regulatory themes in meristem development and whole-plant homeostasis Curr. Opin. Plant Biol. 10(1) 44-51 doi: 10.1016/j.pbi.2006.11.011

8. Marra L M, Fonsecs Sousa Soares C R, Oliveira S M, Avelar Ferreira P A, Soares B L 2012 Biological nitrogen fixation and phosphate solubilization by bacteria isolated from tropical soils Plant Soil 357 289-307 doi: 10.1007/s11104-012-1157-z

9. Kozhemyakov A P, Laktionov Y V, Popova T A, Orlova A G, Kokorina A L, Vaishlya O B, Agafonov E V, Guzhvin S A, Churakov A A, Yakovleva M T 2015 Agrotechnological bases for creating improved forms of microbial biologics for agriculture Agricultural biology 50(3) 369-76 doi: 10.15389/agrobiology.2015.3.369rus

10. Laktionov Y V, Popova T A, Andreev O A, Ibatullina R P, Kozhemyakov A P 2011 Creation of a stable form of growth-stimulating microbiological preparations and their effectiveness Agricultural biology 3 116-8

11. Rashmi P A, Dayana J 2015 Isolation of pesticide tolerating bacteria from cultivated soil in Kerala andthe study of the role of plasmid in pesticide tolerance Int. J. of Pure \& Applied Bioscience 3(1) 109-14

12. Naliuhin A N, Laktionov J V 2015 Efficiency of application of microelement complex Aquamix-T in the cultivation of Galega orientalis in the Northern part of the Non-black earth zone Agriculture 2 25-7

13. Laptiev A B, Kungurtseva O V 2016 Prerequisites and fundamentals of chemical protection of peas from diseases Legumes and cereals 2 99-103

14. Pimokhova L I, Zarapneva Z V 2016 Complex protection of white lupine from Anthracnose Legumes and cereals 3 89-94

15. Potera C 2007 Agriculture: pesticides disrupt nitrogen fixation Environ. Health Persp. 115(12) A579 doi: 10.1289/ehp.115-a579a

16. Moorman T 1986 Effects of herbicides on the survival of Rhizobium japonicum Strains Weed Sci. 34(4) 628-33 doi: 10.1017/S0043174500067564

17. Reganold J P, Papendick R I, Parr J F 1990 Sustainable agriculture Scientific American 262 112-20 doi: 10.1038/scientificamerican0690-112

18. Vance C P 2001 Symbiotic nitrogen fixation and phosphorous acquisition. Plant nutrition in the world of declining renewable resources Plant Physiol. 127 390-7

19. Gopalakrishnan S, Sathya A, Vijayabharathi R, Varshney R K, Gowda C L L, Krishnamurthy L 2015 Plant growth promoting rhizobia: challenges and opportunities Biotech. 5(4) 355-77 doi: 10.1007/s13205-014-0241-x

20. Esedullaev S T, Shmeleva N V 2016 Features of nitrogen accumulation by perennial legumes in pure and mixed crops in the upper Volga region Fertility 6(93) 16-8

21. Mmbaga G W, Mtei K M, Ndakidemi P A 2015 Yield and fiscal benefits of rhizobium inoculation supplemented with phosphorus $(\mathrm{P})$ and potassium $(\mathrm{K})$ in climbing beans (Phaseolus vulgaris L.) grown in Northern Tanzania Agricultural Sciences 6(8) 783-97 doi: 10.4236/as.2015.68076 
22. Laktionov Y V, Belobrova S N, Kozhemyakov A P, Vorobjev N I, Sergaliev N H, Amenova R K, Tlepova A S 2013 Efficiency of legume-rhizobial symbiosis of chickpeas Cicer arientium L.-bacteria Mezorizobium cicer when using mineral fertilizers Fertility 5 24-5

23. Tikhonovich I A, Zavalin A A, Blagoveshchenskaya G G, Kozhemyakov A P 2011 The use of biological products is an additional source of plant nutrition elements Fertility 3 9-13

24. Borzenkova G A, Vasilchikov A G 2014 Application of effective fungicides and flocculants in the technology of cultivation of various soybean varieties Agriculture 4 37-9

25. Borzenkova G A 2014 Optimization of pre-seed treatment technology and the possibility of its combination with inoculation to protect soy from seed infection Legumes and cereals $122-30$

26. Yousaf S, Khan S, Aslam M T 2013 Effect of Pesticides on the Soil Microbial Activity Pakistan J. Zool. 45(4) 1063-7

27. Alam S, Kumar A, Kumar A, Prasad S, Tiwari A, Srivastava D, Srivastava S, Tiwari P, Singh J, Mathur B 2018 Isolation and Characterization of Pesticide Tolerant Bacteria from Brinjal Rhizosphere Int.J.Curr.Microbiol.App.Sci. 7 4849-59

28. Drouin P, Sellami M, Prevost D, Fortin J, Antoun H 2010 Tolerance to agricultural pesticides of strains belonging to four genera of Rhizobiaceae J. of Environmental Science and Health Part B $\mathbf{4 5}$ 780-8 DOI: 10.1080/03601234.2010.515168

29. Deshmukh V V, Raut B TMane, S S, Ingle R W, Josh M S 2014 Compatibility of Bradyrhizobium japonicum isolates with agrochemicals American Int. J. of Research in Formal, Applied \& Natural Sciences 6(1) 55- 62

30. Campo R J, Araujo R S, Hungria M 2009 Nitrogen fixation with the soybean crop in Brazil: Compatibility between seed treatment with fungicides and bradyrhizobial inoculants SYMBIOSIS 48 154-63

31. Tariq M, Hameed S, Shahid M, Yasmeen T, Ali A 2016 Effect of Fungicides and Bioinoculants on Pisum sativum Research \& Reviews: J. of Botanical Sciences 5(2) 36-40

32. Romero-Perdomo F A, Camelo M, Bonilla R 2015 Response of bradyrhizobium japonicum to alginate in presence of pelleted fungicides on soybean seeds Revista U.D.C.A Actualidad \& Divulgación Científica 18(2) $359-64$

33. Rivera D, Obando M, Barbosa H, Tapias D R, Buitrago R B 2014 Evaluation of polymers for the liquid rhizobial formulation and their influence in the Rhizobium Cowpea interaction Univ. Sci. 19 (3) 265-75 doi: 10.11144/Javeriana.SC19-3.eplr

34. Leo Daniel A E, Venkateswarlu B, Suseelendra D, Praveen Kumar G, Mir Hassan Ahmed S K, et al. 2013 Effect of Polymeric Additives, Adjuvants, Surfactants on Survival, Stability and Plant Growth Promoting Ability of Liquid Bioinoculants J. Plant Physiol Pathol. 12

35. Ahemad M, Khan M S 2011 Ecotoxicological assessment of pesticides towards the plant growth promoting activi-ties of Lentil (Lens esculentus)-specific Rhizobium sp. strain MRL3 Ecotoxicology 20(4) 661-9 doi: 10.1007/s10646-011-0606-4

36. Shadab Alam, Adesh Kumar, Arun Kumar, Shambhoo Prasad, Ashutosh Tiwari, Divya Srivastava, Shalini Srivastava, Praveen Tiwari, Jaswant Singh, Bhawana Mathur 2014 Evidence of Fungicides Degradation by Rhizobia Agricultural Sciences 5 618-24

37. McGuinness M, Dowling D 2009 Plant-Associated Bacterial Degradation of Toxic Organic Compounds in Soi Int. J. Environ. Res. Public Health 6 2226-47 
doi:10.3390/ijerph6082226

38. Yakimenko M V, Begun S A, Sorokina A I 2016 Compatibility of collection strains of soybean rhizobia with fungicidal and growth-stimulating drugs Far Eastern agricultural Bulletin 2(38) 38-41

39. Yakimenko M V 2016 Joint use of rhizobia strains and some preparations for pre-sowing treatment of soybean seeds Agriculture 6 46-8

40. Yara Cristiane Buhl Gomes, Flávio Carlos Dalchiavon, Franciele Caroline de Assis Valadão 2017 Joint use of fungicides, insecticides and inoculants in the treatment of soybean seeds Rev. Ceres, Viçosa 64(3) 258-65

41. Fox J E, Gulledge J, Engelhaupt E, Burow M E, McLachlan J A 2007 Pesticides reduce symbiotic efficiency of nitrogen-fixing rhizobia and host plants PNAS 24 10282-7 Doi/10.1073/pnas.0611710104

42. Kozlov G, et al 2020 E3S Web of Conferences $175 \quad 12015$ do:10.1051/e3sconf/202017512015 